\title{
Kozmetik Laboratuvarlarının TS EN ISO/ IEC 17025 Akreditasyonu
}

\section{TS EN ISO/IEC 17025 Accreditation of Cosmetic Laboratories}

Tuğçe Akkaya Bilgiç ${ }^{1}$

Orcid: 0000-0002-6369-9395,

Selin Seda Timur ${ }^{2}$,

Orcid: 0000-0001-9010-3457,

R. Neslihan Gürsoy²,

Orcid: 0000-0002-8589-2321

${ }^{1}$ Türk Akreditasyon Kurumu

(TÜRKAK)

${ }^{2}$ Hacettepe Üniversitesi, Eczacıllk Fakültesi, Kozmetoloji Bilim Dalı, Sihhiye, Ankara, Türkiye

Corresponding author:

R. Neslihan Gürsoy

Hacettepe Üniversitesi, Eczacıllk Fakültesi, Kozmetoloji Bilim Dalı, S1hhiye, Ankara Tel: 03123051241

E-mail: ngursoy@hacettepe.edu.tr

\section{ÖZET}

Akreditasyon; uygunluk değerlendirme faaliyeti yürüten kuruluşlarca gerçekleştirilen çalışmaların ve bu çalışmaların nihai sonucu olarak düzenlenmiş belgelerin güvenilirliğini ve geçerliliğini desteklemek amacıyla oluşturulmuş, serbest ticaret hedefine yönelik olarak sürdürülen bir kalite altyapısıdır [1]. Akreditasyon hizmeti verilen alanlardan biri TS EN ISO/IEC 17025 Deney ve Kalibrasyon Laboratuvarlarının Yeterliliği için Genel Gereklilikler standardı kapsamında deney ve kalibrasyon laboratuvarlarının akredite edilmesidir. Akreditasyon, birçok farklı alan için uygulanabilirdir. Bu alanlardan birisi de kozmetik alanıdır. Ülkemizde kozmetik alanının insan sağlığı üzerindeki etkisi giderek daha da önemli bir hal almıştır. Bu durum, kozmetik uygulamalarının belirlenen standartlarda olması yönündeki talebi de artırmaktadır.

Ülkemizde mevcut durumda 35 adet akredite kozmetik laboratuvarı faaliyet göstermektedir[2]. Kozmetik alanı için akreditasyon, ülkemizde gönüllülük esaslıdır. $\mathrm{Bu}$ durum, faaliyet gösteren kozmetik laboratuvarlarının belirtilen rakamın çok daha üstünde olabileceği yönündeki düşünceyi desteklemektedir. Kozmetik alanında faaliyet gösteren üretici firmalar Türkiye İlaç ve Tıbbi Cihaz Kurumuna (TİTCK) yapılan beyan ile faaliyete geçebilmektedir. Bu firmalar bünyesinde ya da bağımsız şekilde faaliyet gösteren kozmetik laboratuvarları akredite olmak için Türk Akreditasyon Kurumuna akreditasyon başvurusu yapmaktadır.

Bu derleme kapsamında akreditasyon ile ilgili temel kavramlar açıklanarak ülkemizdeki kozmetik laboratuvarlarının TS EN ISO/IEC 17025 akreditasyonu kapsamında yürüttükleri deney faaliyetleri ele alınmaktadır. Sonuç olarak, ülkemizdeki kozmetik laboratuvarları tarafından yürütülen faaliyetlerin kalitesinin artırılmasına yönelik iyileştirme önerileri getirilmektedir.

Anahtar Kelimeler: TÜRKAK, akreditasyon, kozmetik, laboratuvar, ISO 17025

\section{ABSTRACT}

Accreditation is a quality infrastructure tool which supports the credibility and value of the work carried out by conformity assessment bodies for the purpose of free trade and thus of the corresponding attestations issued by them[1]. One of the areas for accreditation service is accreditation of testing and calibration laboratories according to the ISO / IEC 17025 General requirements for the competence 
of testing and calibration laboratories. Accreditation is applicable to many different sectors. One of these sectors is the cosmetic sector. The impact of the growth in the cosmetics on human health has become increasingly important in our country. This increases the demand for cosmetic applications to be in the identified standards.

Currently, there are 35 accredited cosmetic laboratories operating in Turkey and accreditation for cosmetics is voluntary[2]. This situation supports the idea that operating cosmetic laboratories may be much higher than the stated figure. Cosmetics manufacturers can start to operate with the declaration made to the Medicines and Medical Devices Agency. Cosmetic laboratories operating within these companies or independent cosmetic laboratories can apply to the Turkish Accreditation Agency for accreditation. Within the scope of this study, the basic concepts of accreditation are explained and the experimental activities carried out by the cosmetic laboratories in our country within the scope of TS EN ISO / IEC 17025 accreditation are discussed. As a result, suggestions are made to improve the quality of the activities carried out by cosmetic laboratories in our country.

Keywords: TURKAK, accreditation, cosmetic, laboratory, ISO 17025

\section{GİRIŞ}

Türkiye İlaç ve Tibbi Cihaz Kurumu Kozmetik Ürünlerin Analizlerine İlişkin Kılavuz’una göre kozmetikler; "İnsan vücudunun dış kısımlarına; epiderma, tırnaklar, kıllar, saçlar, dudaklar ve dış genital organlarına veya dişler ile ağız mukozasına uygulanmak üzere hazırlanmış, tek veya temel amacı bu kısımları temizlemek, koku vermek, görünümünü değiştirmek, bunları korumak, iyi bir durumda tutmak veya vücut kokularını düzeltmek olan bütün madde veya karışımları" olarak tanımlanmıştır [3]. Tanımdan da anlaşılabileceği gibi, kozmetik kavramının insan vücudunda birden çok uygulama alanı mevcuttur. İnsan vücuduna doğrudan ya da dolaylı olarak karışabilen bu maddelerin insan sağlığ üzerindeki etkileri ise kaçınılmazdır. Bu nedenle, kozmetik ürünlerin kullanım amacına uygun olarak üretilmesi ve analiz edilmesi son derece büyük bir öneme sahiptir. Kozmetiklere uygulanan analizlerde sonuçların sağlam ve güvenilir olması için TS EN ISO/IEC 17025 Deney ve kalibrasyon laboratuvarlarının yeterliliği için genel gereklilikler standardı esaslarına uyulmalıdır.

Ülkemizde kozmetik üreticilerinin piyasa gözetim denetimleri Türkiye İlaç ve Tibbi Cihaz Kurumu tarafindan kozmetik kanunu ve mevzuatlar çerçevesinde yürütülmektedir. Söz konusu kanun ve mevzuatlar kapsamında ise kozmetik laboratuvarları için akreditasyon zorunlu tutulmamakla birlikte akreditasyon standardının gerekliliklerinin karşılanması beklenmektedir. Kozmetik laboratuvarları için bahsi geçen akreditasyon kriteri ise TS EN ISO/ IEC 17025 standardıdır. Bu standart, deney ve kalibrasyon laboratuvarlarının yetkinliği için genel gereklilikleri ifade etmektedir.
Ülkemizde uygunluk değerlendirme kuruluşlarına akreditasyon hizmeti sunan tek kuruluş olarak kurum faaliyetleri ile ilgili düzenlemeleri yapmak, akreditasyon ile ilgili gerekli kıstas ve tedbirleri belirlemek, bunları uygulamak ve gerektiğinde değiştirmek, yürürlükten kaldırmak ve ilgili önlemleri almak, akredite edilmek üzere başvuran kuruluşların ilgili standartlara ve ölçütlere göre denetimini yapmak ve bu denetim sonucunda kuruluşun akredite edilip edilmemesine karar vermek, akredite edilen kuruluşları izlemek, akreditasyonun kapsamını değiştirmek, gerektiğinde akreditasyonu askiya almak veya iptal etmek ve akredite edilen kurum ve kuruluşlar arasında Kurumun görev alanına giren konularda iş birliğini sağlamak yetkileri ise 4457 sayılı kanun ile Türk Akreditasyon Kurumuna (TÜRKAK) verilmiştir [4].

Bu karar ile TÜRKAK, 2000 yılından beri ülkemizdeki kozmetik laboratuvarlarının akreditasyonundan sorumlu olan tek yetkili kurumdur.

$\mathrm{Bu}$ derleme kapsamında, akreditasyon ile ilgili temel kavramlar açıklanarak bu alanda TÜRKAK tarafından yürütülen faaliyetler ele alınmıştır. Bunun dışında, TS EN ISO/IEC 17025 akreditasyonun gereklilikleri açıklanarak akredite olmak isteyen bir kozmetik laboratuvarının sahip olması gereken özellikler ve uygulaması gereken yükümlülükler belirtilmiştir. Ülkemizde akredite olan kozmetik laboratuvarları ve bu laboratuvarlar tarafindan yürütülen kozmetik deneylerine yer verilmiştir. Bu deneylerin hangi ulusal/ uluslararası standart, kılavuz ve dokümanlar çerçevesinde yürütüldüğü açılanmıştır. Son olarak, ülkemizde kozmetik alanında faaliyet gösteren bir kozmetik laboratuvarı için akredite olmanın getirdiği avantajlar belirtilerek bu alanda ülkemizdeki akredite laboratuvar sayısının ve yürütülen faali- 
yetlerin kalitesinin artmasına yönelik önerilere yer verilmiştir. Kozmetik alanında gerçekleştirilen klinik uygulamalar İyi Laboratuvar Uygulamaları (GLP) kapsamında ele alındığ dıșında tutulmuştur.

\section{AKREDITASYON ÍLE ILGILI TEMEL KAVRAMLAR}

\subsection{Akreditasyon ile Ilgili Tanımlar}

\section{Uygunluk Değerlendirmesi}

Uygunluk değerlendirmesi; bir ürüne, sürece, hizmete, sisteme, kişiye veya kuruluşa ilişkin belirli şartların yerine getirilip getirilmediğini gösteren süreci ifade etmektedir.

Uygunluk değerlendirme kuruluşu ise; deney, kalibrasyon, tıbbi deney, muayene, belgelendirme, , yeterlilik testi, referans malzeme üretimi, numune alma ile diğer uygunluk değerlendirme faaliyetlerini gerçekleştiren kuruluştur [4].

\section{Akreditasyon}

TS EN ISO/IEC 17011:2017 standardına göre akreditasyon, "bir uygunluk değerlendirme kuruluşuna ilişkin kuruluşun özel uygunluk değerlendirme görevlerini yerine getirme konusundaki yetkinliğinin resmi olarak gösterilmesini sağlayan üçüncü taraf tasdiki" olarak tanımlanmıştır. Akreditasyon kuruluşu ise "akreditasyonu yerine getiren yetkili kuruluş" olarak tanımlanmıştır.

Akreditasyonun diğer bir tanımı, "kurum tarafından; laboratuvarların, muayene ve belgelendirme, yeterlilik testi, referans malzeme üretimi, numune alma kuruluşları ile diğer uygunluk değerlendirme kuru- luşlarının ulusal ve uluslararası kabul görmüş teknik kriterlere göre değerlendirilmesini, yeterliğinin onaylanmasını ve düzenli aralıklarla denetlenmesini" ifade etmektedir [4].

Dünya genelindeki akreditasyon yapılanması Şekil 1' de gösterilmektedir.

\subsection{TÜRKAK ile IAF/ILAC ve EA Arasındaki Ilişski}

Uluslararasi piyasada mal ve hizmetlerin serbest dolaşımı ve ticaretin önündeki teknik engellerin kaldırılması ve güven içerisinde yapılabilmesi maksadıyla laboratuvarlar, muayene kuruluşları, ürün, sistem ve personel belgelendirme kuruluşlarının akreditasyonunu ülkemizde sadece TÜRKAK yapmaktadır. Uluslararası kurallara ve standartlara göre çalışan TÜRKAK, faaliyetlerinin uluslararası tanınırlığını, üyesi olduğu EA, ILAC ve IAF gibi uluslararası kuruluşlarla imzaladığı karşılıklı tanınma anlaşmalarından almaktadır [6].

\subsection{TÜRKAK'ın Kurumsal Yapısı}

27.10.1999 tarih ve 4457 sayılı Kanun ile uygunluk değerlendirme kuruluşlarını akredite etmek, bu kuruluşların ulusal ve uluslararası standartlara göre faaliyette bulunmalarını ve bu suretle uygunluk değerlendirme kuruluşlarınca düzenlenen belgelerin ulusal ve uluslararası alanda kabulünü temin etmek amaciyla, merkezi Ankara'da olmak üzere Başbakanlıkla ilgili, özel hukuk hükümlerine tabi, tüzel kişiliği haiz, kâr amacı gütmeyen, idari ve mali özerkliğe sahip, Türk Akreditasyon Kurumu, kısa adı ile TÜRKAK kurulmuştur [4].

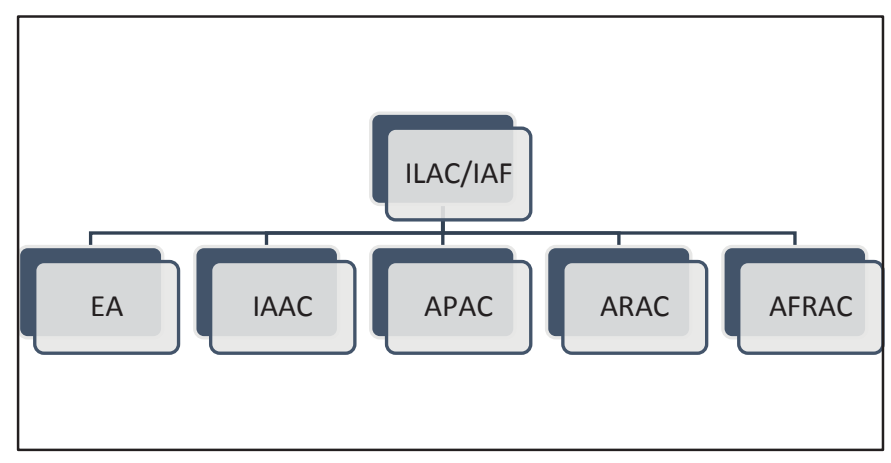

Şekil 1. Dünya genelinde akreditasyon yapılanması[5]. 
TÜRKAK, Tablo 1' de verilen standartlara göre yurt içi ve dışındaki yararlanıcılara aşağıda verilen hizmetleri sunmaktadır.

\section{KOZMETIK}

\section{LABORATUVARLARININ TS EN ISO/ IEC 17025 AKREDITASYONU}

\subsection{Kozmetik Laboratuvarının TS EN}

\section{ISO/IEC 17025 Standardı Kapsamındaki}

\section{Yükümlülükleri}

TS EN ISO/IEC 17025 Standard1 laboratuvarların yetkin çalıştıklarını ve geçerli sonuçlar üretebildiklerini göstermelerini sağlamak amacıyla laboratuvarlar için belirlenmiş gereklilikleri içerir. Standardın içeriği Şekil 2' de gösterilmektedir.

TS EN ISO/ IEC 17025 standard 18 maddeden oluşmaktadır. 1. maddede standardın kapsamı, 2. maddede standardın referans aldığı kaynaklar, 3. maddede ise standardın içerisinde yer alan ifadelere yönelik terim ve tanımlar ifade edilmektedir. 4. maddede deney ve kalibrasyon laboratuvarlarının esas alması gereken genel gerekliliklerden tarafsızlık ve gizlilik hususları ele alınmaktadır. Bu maddeye göre, laboratuvar faaliyetlerini tarafsız bir şekilde yürütecek ve tarafsızlığını sürdürebilecek şekilde yapılandı- rılmalı ve yönetilmelidir. Laboratuvar ve personeli, teknik kararlarını etkileyecek ticari, finansal veya başka herhangi bir baskıdan bağımsız olmalıdır. Test sonuçlarını etkileyecek iç ve dış baskıların göz ardı edileceği garanti altına alınmalıdır. Tarafsızlığa ilişkin riskleri belirleyerek sürekli olarak gözden geçirmelidir.

Standarda göre laboratuvar (komite üyeleri, yükleniciler, iç, dış personel, laboratuvar adına faaliyet gösteren şahıslar da dahil) yönetim sistemi çerçevesinde elde ettiği bütün bilgilerin yönetiminden yasal yükümlülükler doğrultusunda sorumludur ve tüm bilgileri gizli tutmalıdır. Laboratuvar kamuya açık hale getirmek istediği bilgileri önceden müşteriye bildirmelidir. Aynı zamanda laboratuvar, hangi yasal yükümlülüklere tabii olduğunu bilmelidir. (6698 sayılı Kişisel Verilerin Korunması Kanunu, GDPR vb.) Gizliliğin sağlanmasına ilişkin gereklilikler müşseri ile yapılacak sözleşmede garanti altına alınmalıdır [7].

Yapısal gerekliliklerinin belirtildiği 5. maddeye göre, laboratuvarın sahip olduğu tüzel kişiliğe göre (kamu, özel, belediye, üniversite, KİT, büyük bir şirketin yapısındaki laboratuvar vb.) yasal kimliğini gösteren dokümanlara sahip olması istenmektedir. Laboratuvar, TS EN ISO/IEC 17025 satandardına uygun olan laboratuvar faaliyetlerinin kapsamını tanımlamalı ve dokümante etmelidir. Laboratuvar standarda uygunluğu yalnızca tanımlanan kapsam için beyan etmeli, sürekli olarak dışarıdan tedarik edilen faaliyetler hâriç tutulmalıdır.

Tablo 1. TÜRKAK tarafından sunulan hizmetler [4]

\begin{tabular}{cc}
\hline Hizmetin Konusu & İlgili Standart \\
\hline Tıbbi Laboratuvarların Akreditasyonu & TS EN ISO/IEC 17025 \\
Yeterlilik Deneyi Sağlayıcılarının Akreditasyonu & TS EN ISO 15189 \\
İyi Laboratuvar Uygulamaları (İLU) & TS EN ISO/IEC 17043 \\
Muayene Kuruluşlarının Akreditasyonu & OECD GLP Prensipleri \\
Ürün Belgelendirme Kuruluşlarının Akreditasyonu & TSE EN ISO/IEC 17020 \\
Sistem Belgelendirme Kuruluşlarının Akreditasyonu & TS EN ISO/IEC 17065 \\
Personel Belgelendirme Kuruluşlarının Akreditasyonu & TS EN ISO/IEC 17021 \\
Referans Malzeme Üreticilerinin Akreditasyonu & TS EN ISO/IEC 17024 \\
Sera Gazları Doğrulama Kuruluşlarının Akreditasyonu & TS ISO 17034 \\
\hline
\end{tabular}




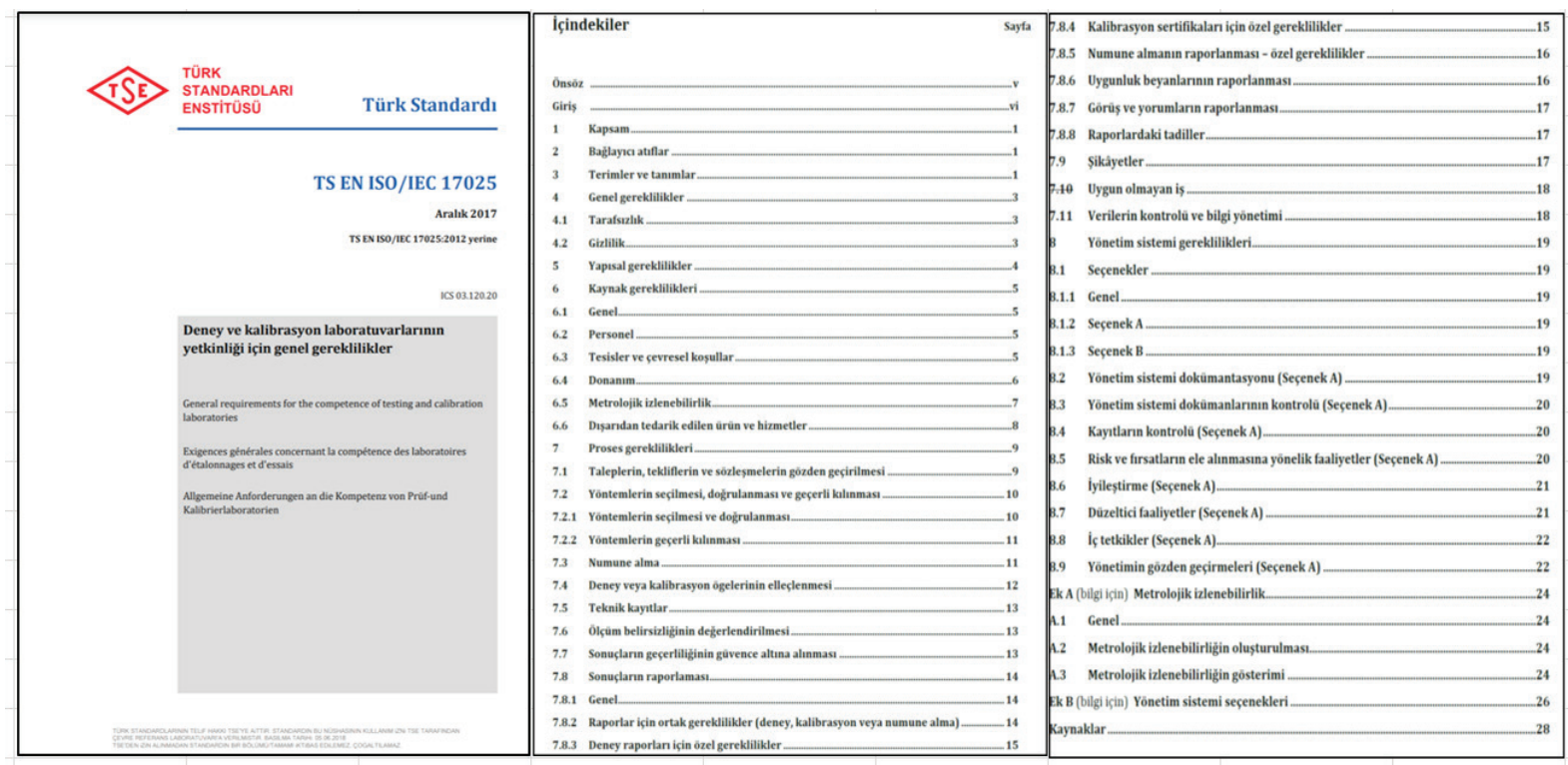

Şekil 2 TS EN ISO/ IEC 17025 standardı içeriği [7]

6. maddede laboratuvarın bu standarda uygun bir yönetim sistemi oluşturarak sürdürebilmesi için gerekli kaynaklar; yetkin personel, uygun tesis ve çevresel koşullar, metrolojik izlenebilirliği sağlayan donanım ve ihtiyaç duyulması durumunda ürün ve hizmetlerin dışardan tedarik edilmesine yönelik bir sistem olarak tanımlanmaktadır. Standardın gerekliliklerine göre faaliyet gösteren bir laboratuvar, icra edilen faaliyete uygun ve yetkin iç ve/veya dış personele sahip olmalıdır[7]. Laboratuvar, bütün personelini (iç veya diş personel) yönetim sistemine uygun olarak istihdam etmelidir. Bütün personel için iş sözleşmeleri, her durumda yazılı olmak şartıyla 4857 sayılı İş Kanunu hükümlerine uygun olmalıdır. 4857 sayılı İş Kanunu'nda yazılı olarak yapılma şartı bulunmayan çalışma tipleri için de laboratuvar ve ilgili personel arasında, çalışma şartları gibi hususları belirten bir sözleşme yazılı olarak yapılır [8]. Laboratuvar personelinin yetkinliği için kriterleri kendi yönetim sistemi ve laboratuvar faaliyetine özgü olarak belirlemeli ve dokümante etmelidir. Laboratuvar yönetimi, personelini belirlemiş olduğu yetkinlik kriterlerine göre seçmek ve personele görev, sorumluluk ve yetkilerini bildirmekle yükümlüdür. Laboratuvar deney faaliyetlerinde kapsamlarında yer alan metotların geliştirilmesi, doğrulanması ve/veya geçerli kılınmaS1 çalışmalarını, görüş ve yorumları da içerebilecek sonuçların analizi, sonuçların raporlanması, gözden geçirilmesi, onaylanmasında vb. yetkinlik gerekti- ren laboratuvar faaliyetlerini yürütecek personelini yetkilendirmelidir. Tüm bunlara yönelik olarak laboratuvarın bir prosedür oluşturması ve kayıt tutması beklenmektedir.

Laboratuvarda gerçekleştirilen faaliyete göre uygun çevresel gereklilikler dokümante edilmelidir. Laboratuvarın gereklilikleri karşılayıp karşılamadığının değerlendirilmesi adına gerekli izlemeler, kontroller yapılmalı ve kayıtlar tutulmalıdır. Çevre koşullarının sağlanmasında odak noktası ilgili deney standard1nın gereklilikleri olmalıdır[7].

Laboratuvar tarafından kullanılmak üzere seçilen donanım ve yazılım, bir deney ortamında kullanıldığında doğru ölçümler alabilmelidir. Bir laboratuvarın belirli bir amaç için bir donanım parçasını kiralama ihtiyacı varsa, kiralanan donanım tüm laboratuvar gerekliliklerini ve standardın gerekliliklerini karş1lamalıdır[9].

Güvenilir ölçümler, yetkin personele, doğrulanmış ve test edilmiş prosedürlere, kapsamlı kalite sistemlerine ve uygun ölçüm referanslarına göre izlenebilirliğe bağlıdır. Sonuçların zaman ve mekanda karşılaştırılabilirliğini sağlamak için tüm bireysel ölçüm sonuçlarının bazı ortak, kararlı referans veya ölçüm standartlarına bağlanması önemlidir. Sonuçlar, bu referansla olan ilişkileri aracılığıyla karşılaştırılabilir. Sonuçları bir referansa bağlama stratejisine "metrolojik izlenebilirlik" adı verilir [10]. 
Metrolojik izlenebilirlik, ölçüm sonucunun bir ölçüm belirsizliği beyanı çerçevesinde ulusal ve uluslararası standartlara uygunluğu hususunda bir güven oluşturmaktadır. $\mathrm{Bu}$ nedenle cihazların uygun aralıkta ve uygun taraflarca kalibrasyonunun gerçekleştirilmesi ölçüm sonuçlarını ve belirsizlik tahminlerinin büyüklüğüne olan güveni önemli ölçüde etkilemektedir. Tüm bunlar göz önünde bulundurulduğunda Metrolojik İzlenebilirlik ISO/IEC 17025 akreditasyonunun önemli bir gerekliliğidir [11].

TS EN ISO/IEC 17025:2017 Standardına göre cihazların metrolojik izlenebilirlik gereklilikleri "ILAC P10 Ölçüm Sonuçlarının İzlenebilirliğine İlişkin ILAC Politikası" rehberinde metrolojik izlenebilirlikle ilgili rotaları aşağıdaki şekilde üç rota altında değerlendirmiştir.

Rota-1: Hizmeti söz konusu ihtiyaç için uygun olan ve Uluslararası Ağırlıklar ve Ölçüler Komitesi Karşı1ıklı Tanıma Anlaşması (CIPM MRA) tarafından kapsanan bir Ulusal Metroloji Enstitüsü (UME). CIPM MRA kapsamındaki hizmetler

Rota-2: Hizmeti söz konusu ihtiyaç için uygun olan (yani akreditasyon kapsamı talep edilen kalibrasyonu içeren) ve ILAC anlaşması veya ILAC tarafından tanınan bölgesel anlaşmalar kapsamındaki bir akreditasyon kuruluşu tarafindan akredite edilen kalibrasyon laboratuvarı.

Rota-3: a) Hizmeti söz konusu ihtiyaç için uygun olan ancak CIPM MRA kapsamında olmayan bir UME

b) Kalibrasyon hizmeti söz konusu ihtiyaç için uygun olan ancak ILAC Anlaşması veya ILAC tarafindan tanınan Bölgesel Anlaşmalar kapsamında olmayan bir laboratuvar. [12].

Ülkemizde Rota 1 ve 2 yoluyla metrolojik izlenebilirlik sağlanabilir durumdadır. Bu nedenle Rota 3'ün tercih edilmesi izlenebilirlik gerekliliklerinin sağlanması için geçerli bir yol değildir. Sadece kalibrasyonun akredite laboratuvarlarda mevcut olan metotlara göre yapılamadığ ekipmanın çok karmaşık olması veya kalibrasyon için sadece üreticinin uygun altyapıya sahip olması vb.) üçüncü rotanın kullanımına izin verilebilir [13]. Sadece ekonomik veya lojistik gerekçeler sebebiyle 3. rotadan metrolojik izlenebilirlik sağlanması yoluna gidilemez.

Deney faaliyeti gerçekleştiren laboratuvarlar faaliyetleri sırasında ihtiyaç duydukları ölçüm standart- ları, donanım, yardımcı donanım, sarf malzemeleri, referans malzemeler gibi ürünler ile, deney, kalibrasyon, numune alma, bakım, onarım, yeterlilik deneyleri, tetkik gibi hizmetleri dışarıdan tedarik edebilir. Burada esas olan laboratuvarın kendi akreditasyon kapsamında yer alan laboratuvar faaliyetini sadece geçici süreliğine dışarıdan tedarik edebileceğidir. Yani laboratuvar sürekli bir dış tedarikçi kullandığı, yeterli kaynağa ve yetkinliğe sahip olmadığı faaliyetleri için akreditasyon başvurusunda bulunamaz veya bu faaliyetleri için akreditasyonları sürdürülemez. Laboratuvar kullanacağı dış tedarikçilerin seçimi, değerlendirilmesi, izlenmesi ve yeniden değerlendirilmesi için bir sistem oluşturmalıdır. Buna yönelik olarak dış tedarikçi yetkinlik için gereklilikleri, seçim kriterlerini tanımlamalı, bunları düzenli olarak kontrol etmeli ve gerekli ise ek ihtiyaçlar doğrultusunda revize etmelidir[7].

Laboratuvar mücbir sebepler hariç, dışarıdan aldığ 1 laboratuvar faaliyeti hizmetlerini yapılacak olan işe uygun olarak TÜRKAK tarafindan veya TÜRKAK'ın taraf olduğu tanınma anlaşmaları ile deney alanında tanınırlık anlaşması olan bir akreditasyon kurumu tarafindan talep edilen faaliyette akredite kuruluştan alır [8].

7. maddede ise laboratuvarın yürüttüğg̈ uygunluk değerlendirme faaliyetlerine yönelik proses gereklilikleri ele alınmaktadır.

Laboratuvarın deney faaliyetlerine yönelik süreci müşteri talebi ile başlamaktadır. Laboratuvar taleplerin, tekliflerin ve sözleşmelerin gözden geçirilmesi için bir prosedüre sahip olmalıdır. Bu prosedürler; müşteri talebine yönelik laboratuvarın yeterli kaynağa ve yetkinliğe sahip olduğunu, talep ile ilgili faaliyetin herhangi bir aşaması dış tedarikçi tarafından gerçekleştirilecekse müşterinin dış tedarikçi hakkında bilgilendirilmesi ve onaylanması sürecini, talep ile ilgili seçilen yöntemin talebin gerekliliklerini karş1layacağını garanti alacak şekilde oluşturulmalıdır. Müşteri ile yapılan sözleşmede herhangi bir değişiklik olması durumunda müşterinin bilgilendirilmesi süreci tanımlanmalıdır.

Müşteri talebine yönelik seçilecek yöntem müşteri tarafından bildirilmemişse laboratuvar tarafindan seçilen yöntem hakkında müşteri bilgilendirilmelidir. Yöntem seçiminde mevcut olan güncel yöntemlerin kullanılması esastır. Kullanılacak yöntemin laboratuvarın çalışma koşullarına uygunluğunun kanıtlanması için doğrulanmalıdır. Laboratuvar standart ol- 
mayan bir yöntem kullanacak ise yöntemin geçerli kılma çalışmaları tamamlanmalıdır.

Kozmetik laboratuvarlarında yürütülen analizlere ilişkin kalitenin güvencesinin sağlanmasının bir yolu da dış kalite kontrol programlarıdır. Laboratuvarlar, asgari olarak standardın ön gördüğü iç ve dış kalite kontrol faaliyetlerinden kendi faaliyetlerine uygun olanı/olanlarını gerçekleştirir [13].

TÜRKAK tarafından akredite olmak isteyen ve verilmiş olan akreditasyonu sürdürmek isteyen kozmetik laboratuvarları teknik yeterliliklerini göstermek ve bu yeterliliği izlemek için gerekli çalışmaları yapmaktan sorumludur. Teknik yeterliliği göstermenin bir yolu laboratuvarların mevcut ve uygun olan yeterlilik deneylerine katılımı ve başarılı sonuçlar elde etmesidir. Diğer yollar referans malzemelerin düzenli kullanımını ve aynı veya farklı metotları kullanarak deney ya da kalibrasyonların tekrar yapılmasını içerebilir. Yeterlilik deneyleri ve laboratuvarlar arası karşılaştırma programları TS EN ISO/IEC 17043 standardı şartlarını karşılamalıdır [13].

Laboratuvar, deney ögesinin bütünlüğü ile laboratuvar ve müşterinin çıkarlarının korunması için gereken tüm tedbirler dahil, deney öğelerinin taşınması, kabulü, elleçlenmesi (numunenin işlenmeye hazır hale getirilmesi), korunması, depolanması, alıkonulması ve bertarafı veya geri gönderilmesi için bir prosedüre sahip olmalıdır.

Ölçüm belirsizliği; değerlerin, ölçülen büyüklük ile ilişkilendirilebilecek dağılımını tanımlayan, ölçüm sonucu ile ilgili bir parametredir. Bir başka deyişle, \pm 'den sonra gelen sayıdır[14]. Örneğin, $10 \pm 1 \mathrm{mg} / \mathrm{L}$ şeklinde verilen bir sonuç normalde, gerçek değer 9-11 mg/L aralığındadır şeklinde yorumlanır. Laboratuvar belirsizlik değerini doğru tahmin etmişse bu yorum geçerlidir. Tüm ölçümler belirli bir hatadan etkilenir. Ölçüm belirsizliği, bize ölçüm hatasının ne kadar büyük olabileceği hakkında bilgi verir. Bu nedenle ölçüm belirsizliği, raporlanan sonucun önemli bir parçasıdır [15].

Laboratuvar, mümkünse ölçüm sonucunu ve ilişkili ölçüm belirsizliğine etki eden unsurların tanımlanmasını kolaylaştırmak ve laboratuvar faaliyetinin aslına mümkün olan en yakın şartlar altında tekrarına imkân tanımak için her bir laboratuvar faaliyetine ilişkin teknik kayıtların; sonuçları, raporu ve yeterli bilgiyi içerdiğini güvence altına almalıdır. Teknik kayitlar manuel veya elektronik ortamda tutulmuş olabilir. Her iki durumda da gerçekleştirilen deği- şikliklere ilişkin kayıtlar; yapılan değişikliğin içeriği ve değişiklikten sorumlu personel bilgisini içerek şekilde saklanmalıdır. Böylelikle veri ve kayıtların izlenebilirliğinin garanti altına alınması sağlanabilir.

TS EN ISO/IEC 17025:2017 standardının madde 7.7 sonuçların geçerliliğinin güvence altına alınması maddesi; laboratuvarların, gerçekleştirdikleri deney faaliyetlerinin çıktısı olan sonuçlarının sürekli olarak beklenen kalitede olmasını sağlamaya yönelik gerçekleştirmeleri beklenen iç ve dış kalite kontrol çalışmaları ile ilgili şartları içerir.

TS EN ISO/IEC 17025:2017 Standard1 laboratuvar tarafindan üretilen raporlarda deney faaliyetine göre nelerin yer alması gerektiği konusunda oldukça spesifiktir; fakat aynı zamanda bilgilerin doğru, açık, kesin ve tarafsız bir şekilde ve açıklanmadan önce kontrol edilip onaylanarak raporlanması yönünde genel bir gerekliliğe sahiptir[7].

Laboratuvarlar için deney raporlarının oluşturulmasina yönelik TÜRKAK prensipleri R20-18 TURKAK Markalı Deney Raporları ve Kalibrasyon Sertifikalarına İlişkin Rehber'de de tanımlanmıştır.

Standardın 7.8 Sonuçların raporlanması başlığında laboratuvarın analiz sonucuna ilişkin müşteriye uygunluk beyanı vermesi durumunda bir karar kuralı belirlemesi gerekliliği yer almaktadır. Karar kuralı, belirlenmiş bir gerekliliğe uygunluğu belirtirken, ölçüm belirsizliğinin nasıl hesaba katılacağını açıklayan kuraldır[16]. Örneğin; kozmetik laboratuvarı cilt kremi için uyguladığ 1 bir analiz sonucunda müşterisine uygunluk beyanı vereceği durumda, ölçüm belirsizliğini ölçüm sonucuna hangi kurala göre dahil edeceğini belirlediği bir karar kuralını dokümante etmelidir. Burada bahsedilen uygunluk beyanı ise analiz edilen kozmetik ürüne ait parametrelerin sahip olması gereken alt ve üst limitlere uygunluğudur.

Bir kozmetik ürün için alt ve üst limitler Türkiye İlaç ve Tıbbi Cihaz Kurumu (TİTCK) tarafindan belirlenen yönetmelik ve kılavuzlarda yer almaktadır [17]. Kozmetik laboratuvarları analiz ettikleri ürünlerin bu yasal gerekliliklere uygunluğunu değerlendirmelidir. TÜRKAK markasının kullanımına yönelik daha detaylı bilgiler ise R10-06 TÜRKAK Akreditasyon Markasının Akredite Kuruluşlarca Kullanılmasına İlişkin Şartlar rehberinde ele alınmaktadır.

ISO/IEC 17025:2017 standardında şikâyet, herhangi bir kişi ya da kuruluşun laboratuvarın faaliyetleri veya sonuçlarıyla ilgili olarak laboratuvara 
bildirdiği, cevaplandırılması gereken memnuniyetsizlik olarak tanımlanmaktadır. Laboratuvarın tüm müşteri şikâyetlerini kaydetmesi, sistematik olarak araştırması ve soruşturmaların sonucunu ve alınan düzeltici önlemleri kaydetmesi gerekmektedir. Laboratuvar ISO/IEC 17025:2017 standard1 gereğince şikâyetlerin alınması, değerlendirilmesi ve karar verilmesiyle ilgili bir prosese sahip olmalıdır. Aynı zamanda dokümante edilen bu proses, ilgili tarafların erişimine açık olmalıdır.

Laboratuvarların standart gerekliliklerinden, kendi prosedürleri veya müşteri prosedürlerinden sapmaları, yanlış bir sonuç raporlaması, uygun olmayan yeterlilik testi veya laboratuvarlar arası karşılaştırma sonucu elde etmesi, belirli bir şartın sağlanmadığına dair kanıt elde edilmesi durumları uygun olmayan iş olarak ele alınabilir. Uygun olmayan iş; denetim, müşteri şikâyetleri ve geri bildirimleri, kalite kontrol verileri, uygunsuz yeterlilik testi veya gözlem sonucu tespit edilebilir [7]. Bu durumda laboratuvar, uygun olmayan işe yönelik prosedürünü oluşturmalıdır. Laboratuvar uygun olmayan bir iş ile karşılaştığında buna yönelik olarak gerçekleştireceği faaliyetin kararını ve ilgili aksiyonu ivedilikle almalıdır. Laboratuvar ilgili uygunsuz işin tekrar gerçekleşme olasıllı̆ 1 ve etkisini göz önünde bulundurarak kök sebep analizini de kapsayan düzeltici faaliyet gerçekleştirmesi ve düzeltici faaliyetin etkinliğini gözden geçirmesi, eğer gerekli ise kalite yönetim sisteminde değişiklik yapması uygun bir yaklaşım olacaktır. Böylelikle uygunsuz işin tekrarlanması olasılığının önüne geçilmiş olacaktır.

Laboratuvarlarda kalite yönetim sistemi ve laboratuvar faaliyetleri göz önünde bulundurulduğunda oldukça fazla veri üretimi söz konusudur. Verilerin toplanması, işlenmesi, kaydedilmesi, raporlanması, depolanması veya veriye tekrar ulaşılması için kullanılan laboratuvar bilgi yönetim sistemi/sistemleri; ara yüzlerin laboratuvar bilgi yönetim sisteminde düzgün işleyişi de dâhil, kullanım öncesi fonksiyonellik açısından geçerli kılınmalıdır ya da doğrulanmalıdır. Laboratuvar yazılım yapılandırması veya hazır ticari yazılımlardaki değişiklikler de dahil, herhangi bir değişiklik olduğunda, bu değişiklikler uygulanmadan önce onaylanmalı, dokümante edilmeli ve geçerli kılınmalıdır[7,18].

ISO/IEC 17025 standard1, laboratuvarlara yönetim sistemi için Seçenek A ve Seçenek B olmak üzere iki seçenek sunmaktadır. Laboratuvara sunulan se- çeneklerden ilki "Seçenek A" laboratuvarın yönetim sistemi gereklilikleri olarak tanımlanmış maddelere uygun olarak işletilmesi şeklindedir. Yani laboratuvar sadece ISO/IEC 17025 Standardını referans alarak bir yönetim sistemi işletir[7].

Diğer Seçenek olan "Seçenek B" ise laboratuvarın ISO/IEC 17025:2017 Standardının Yönetim Sistemi Gereklilikleri yerine ISO 9001 Standardının gerekliliklerinin yerine getirmesi şeklindedir. Yani laboratuvar ISO/IEC 17025:2017 Standardının Genel Gereklilikleri, Yapısal Gereklilikler, Kaynak Gereklilikleri ve Proses Gerekliliklerinin yanı sıra ISO 9001 standardının gerekliliklerini sağlamalıdır.

TÜRKAK R20.43 rehberinde de belirtildiği gibi; akreditasyon denetimleri açısından seçenekler arasında farklı bir uygulama bulunmamaktadır. Her iki seçenek için de akreditasyon asgari olarak Seçenek A'da belirtilen gereklilikleri karşılayan bir yönetim sisteminin oluşturulup oluşturulmadığını denetlenmektedir[8].

Laboratuvar yönetimi, bu standardın amaçlarını gerçekleştirmek için politika ve hedefler oluşturmalı, bunları dokümante etmeli, sürekliliğini sağlamalı; bu politika ve hedeflerin laboratuvar organizasyonunun tüm seviyelerinde kabul edilmesini ve uygulanmasını güvence altına almalıdır. Laboratuvar faaliyetlerinde yer alan bütün personel, yönetim sistemi dokümantasyonunun bölümlerine ve kendi sorumluluklarına uygulanabilir olan tüm güncel bilgilere ulaşabilmelidir.

Laboratuvar yönetim sistemi kapsamında bulunan tüm dokümanlar için dokümanın yayımlanmadan önce uygunluğunun yetkili bir personel tarafından onaylanmasından, ihtiyaca ya da yasal gereklilik düzenlemeleri vb. doğrultuda dokümanlarda gerekli olan revizyonların gerçekleştirilmesinden ve periyodik olarak gözden geçirilmesinden, dokümanların tanımlanması ve dağıtımının kontrolünden, güncel olmayan dokümanların kullanılmamasına yönelik alınacak tedbirlerden sorumludur. Deney faaliyetlerinin gerçekleştirildiği alanlarda bulunması gereken dokümanlar tanımlanmalıdır.

$\mathrm{Bu}$ noktada laboratuvar kalite kayıtları ve teknik kayıtlar olmak üzere iki ana başlıkta değerlendirme yapabilir. Kayıtların kalite ve teknik olarak ayrılması laboratuvara kullanımda kolaylık sağlayabilir. Kalite kayıtları deney faaliyetleri için gerekli olan kalite gerekliliklerinin sağlanmasını ve etkin olarak işletilmesini sağlayan kayıtlardır. İç tetkik, yönetimin 
gözden geçirilmesi, düzeltici faaliyet ve iyileştirme kayıtlarını içerirken teknik kayıtlar deney faaliyetleri için gerekli olan deney prosedürlerinin uygulanması, ham veriler, dokümanlarındaki izlenebilirliğin sağlanmasına yönelik kayıtlar, kullanıcılara yapılan beyanlar, formlar ve sözleşmeleri içerebilir. Bu kayıtlar elektronik ortamda ya da basılı olabilmektedir. Elektronik ortamda tutulan kayıtların geçerli bir yazılım ile korunduğundan emin olunmalıdır.

Risk ve firsatların değerlendirilmesi kavramı TS EN ISO/IEC 17025:2017 standardı ile birlikte laboratuvarlar için daha fazla önem kazanmış olup proaktif bir yaklaşım sergilenmesi beklentisi dile getirilmektedir.

ISO Guide 73/ TS ISO 31000 standardına göre ise risk kavramı 'hedefler üzerindeki belirsizlik etkisi' firsat ise 'riskin olumlu yanları ve sağlayabileceği olası kazançları' olarak tanımlanmaktadır[19]. Risk Yönetim Enstitüsü (IRM) riski 'Bir olayın sonuçlar1nın ve olayın oluşmasına ilişkin olasılığın bir kombinasyonu' olarak ifade etmektedir.

TS EN ISO/IEC 17025:2017 Standardı aşağıdaki maddelerde risk terimine açıça değinmektedir:

- Önsöz,

- Giriş,

- Madde 4.1.4 ve 4.1.5 Tarafsızlık

- Madde 7.8.6.1 Raporlarda kullanılan karar kuralında risk teriminin dikkate alınması

- Madde 7.10.1 Uygun olmayan işlerin yönetimi

- Madde 8.5 Riskleri ve firsatların ele alınmasına yönelik faaliyetler

- Madde 8.6 İyileştirme

- Madde 8.7 Düzeltici faaliyet

- Madde 8.9 Yönetimin Gözden Geçirmesi

Risk değerlendirmesi; değişen durumlara göre güncellenmesi gereken, iyileştirmeye yönelik aksiyonların sürekli izlenmesini ve tekrar değerlendirmesini içeren bir süreçtir. Risk yönetimi bir defaya mahsus yapılan bir faaliyet değildir [20].

Laboratuvar, gerçekleştirdiği deney faaliyetleri ile ilgili olarak yönetim sistemi için oluşturulmuş politika ve prosedürlerden herhangi bir sapmanın yaşanması durumunda düzeltici faaliyetlerin gerçekleştirilmesi için harekete geçmelidir. Gerçekleştirilen düzeltici faaliyetler uygunsuzluğun büyüklüğü ve karşılaşıla- bilecek risklerle orantılı olmalıdır. Düzeltici faaliyet gerçekleştirilmesi ihtiyacı; deney faaliyetleri sürecinde gerçekleştirilen çalışmalar sırasında ortaya çıkan problemler, personelin gözlemleri, iç ve dış tetkikler, yönetimin gözden geçirmesi, kalite yönetim sisteminin yürütülmesine yönelik gerçekleştirilen faaliyetler, katılım sağlanan laboratuvarlar arası karşılaştırma ve yeterlilik deneyleri ile müşterilerden gelen öneri ve şikayetlerden tespit edilebilir[7]. Herhangi bir düzeltici faaliyet gerçekleştirmeden önce uygunsuzluğun sebebi açı bir şekilde ortaya konulmalı ve anlaşıldığından emin olunmalıdır. Gerçekleştirilen düzeltici faaliyetten maksimum fayda sağlamak isteyen bir laboratuvar uygunsuzluğun nedeni için bir kök neden analizi gerçekleştirmek ve esas nedeni tanımlamak konusunda 1srarcı olmalıdır.

Eğer tespit edilen uygunsuzluk TS EN ISO/ IEC 17025 standardının gerekliliklerini yerine getirmek hususunda şüphe uyandırıyorsa laboratuvar rutinin dışında iç tetkik düzenleyebilir.

İç tetkik ifadesi bir laboratuvarın faaliyetlerinin ne ölçüde yerine getirildiğini belirlemek için objektif kanıt elde etmek ve objektif olarak değerlendirmek için sistematik, bağımsız ve dokümante edilmiş süreç olarak tanımlanabilir[21].

Laboratuvar, düzenli aralıklarla, belirlenmiş çizelge ve prosedürlere uygun olarak deney faaliyetlerinin uygunluğunu değerlendirmek için iç tetkik gerçekleştirmelidir. İç tetkiki gerçekleştiren personel, tetkik edilecek faaliyetten bağımsız, eğitimli ve nitelikli olmalıdır. İç tetkik personeli için belirlenen yetkinlik kriterleri yazılı hale getirilmelidir. İç kaynakların yeterli olmadığı durumlarda veya tercih edilmesi halinde dış kaynaklardan da yararlanılarak iç tetkik faaliyeti yerine getirilebilir. Laboratuvar iç tetkik için her bir birimin yetkinliğini ölçebilecek nitelikte soru listesi oluşturmalıdır. Hazırlanan iç tetkik soru listesi yalnız TS EN ISO/IEC 17025 standardının gerekliliklerini değil aynı zamanda TÜRKAK, EA, ILAC vb. organizasyon gereklilikleri ve yasal otorite beklentilerini de karşılayacak nitelikte olmalıdır. Soru listesi hazırlanırken yanıtların objektif olarak değerlendirilebileceği nitelikte olmasına da özen gösterilmelidir.

TÜRKAK gerekliliklerine göre, TS EN ISO/IEC 17025 kapsamında ilk akreditasyon için başvuran laboratuvarlar talep edilen akreditasyon kapsamında yürütülen faaliyetlerin tümüne yönelik iç tetkik faaliyeti yürütmeli ve kayıtlarını TÜRKAK' a sunmalıdır[22]. 
Laboratuvar, iç tetkik sürecinin planlaması ve yönetilmesi hususunda TS EN ISO/IEC 17025 standard1nın da kılavuz olarak önerdiği ISO 19011 standardından da yararlanabilir[7].

İç ve dış denetim sonuçları, faaliyet alanındaki ve teknolojideki değişimler, müşteri şikâyetleri vb. yönetim sistemi veya laboratuvar faaliyetlerinde değişiklik yapılması ihtiyacı doğurabilir. Bu değişiklik ihtiyacının tespit edilmesi Yönetimin Gözden Geçirmesi (YGG) faaliyeti ile sağlanabilmektedir. $\mathrm{Bu}$ yolla laboratuvar hem yönetim sisteminin hem de laboratuvar faaliyetlerinin uygun ve etkin olup olmadığını tespit ederek iyileştirme ve geliştirme için gerekli olan adımları atabilir.

\subsection{TÜRKAK Laboratuvar Akreditasyon}

\section{Süreçleri}

Kozmetik laboratuvarları tarafından gerçekleştirilen deney faaliyetlerinin akreditasyonu ile ilgili hususlar TÜRKAK P701 Uygunluk Değerlendirme Kuruluşlarının Akreditasyonu Prosedürü'nde belirtilmektedir.

Bunun yanı sıra laboratuvarlara özgü ek gereklilikleri tanımlamak üzere oluşturulmuş "R20.43 Laboratuvarların Akreditasyonuna Dair Rehber” gereklilikleri uygulanmaktadır. P701 prosedüründe Uygunluk Değerlendirme Kuruluşlarının (UDK) akreditasyon başvurularının TÜRKAK tarafından nasıl ele alındı ̆̆ı, değerlendirildiği, akreditasyon denetimi türleri hakkındaki bilgiler, denetim süreci, akreditasyonunun askıya alınması, geri çekilmesi ve kapsamının daraltılması veya kapsamın genişletilmesi ile ilgili durumlar ve akredite kuruluşların yükümlülükleri açıklanmaktır. R20.43 rehberinde ise, bu bilgilere ek olarak, laboratuvar akreditasyonu için TS EN ISO/
IEC 17025 standardi gereklilikleri ve risk temelli denetim planlamasına yönelik bilgiler yer almaktadır. TÜRKAK akreditasyon süreci gerekliliklerine göre;

Akreditasyon süreci aşağıda belirtilen ana safhalardan oluşur. Bunlar;

1. Başvuru,

2. Denetim öncesi yapılan hazırlıklar,

3. Öndenetim (başvuran kuruluş tarafindan talep edildiğinde),

4. Akreditasyon denetimi,

5. Denetim sonrası yapılan değerlendirmeler (takip denetimi dahil),

6. Karar,

7. Gözetim,

8. Akreditasyonun yenilenmesi

Akreditasyon denetimlerinin periyotları Şekil 3' de verilmektedir.

Kozmetikler, Kozmetik Ürün Güvenlik Değerlendirme Kılavuzuna göre güvenli olmak zorundadır. Bunun için kozmetik ürünlerde belli analizlerin yapılması gerekmektedir. Güvenli kozmetik ürün için yapılması gereken testler aşağıda belirtilmektedir.

Fiziksel analizler: Ürünün niteliğine ve teknolojisine göre; renk, koku, görünüm, $\mathrm{pH}$, yoğunluk, viskozite gibi özellikleri mutlaka analiz edilmelidir.

Stabilite testi: Bir kozmetik ürünün, normal şartlar altında, başlangıçtaki fonksiyonlarını yerine getirmeye devam ettiği ve güvenli olmaya devam ettiğini gösteren stabilite çalışmaları, izlenen özellikleri ve test sonuçları özellikle raf ömrü 30 ayı geçen ürünlerde test yöntemleri ve sonuçları ile birlikte tablo halinde verilmelidir.

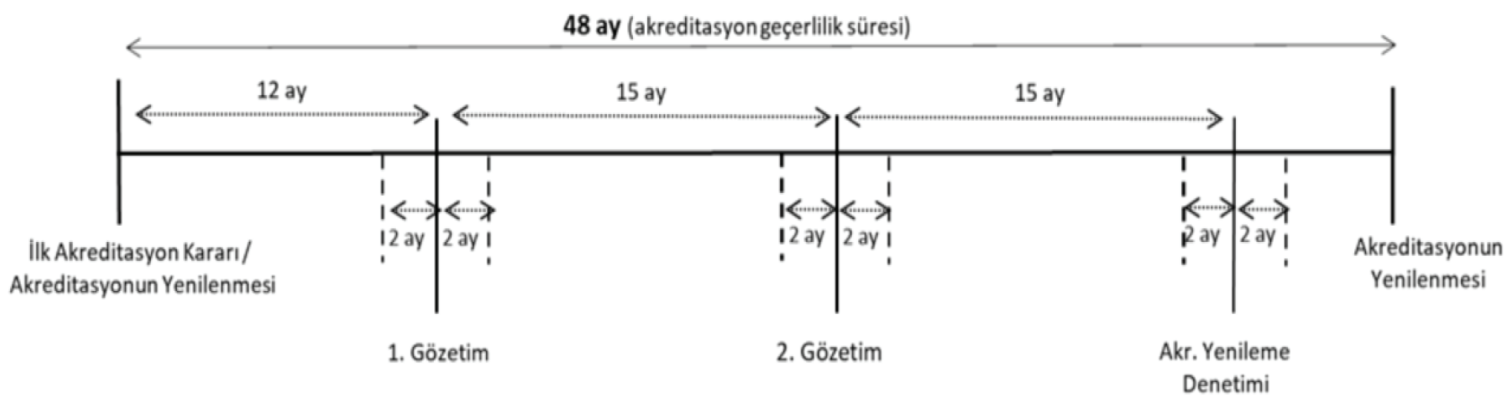

Şekil 3. Akreditasyon çevrimi içerisindeki denetim periyotları [22] 
Ăğır metal analizleri: Özellikle renkli kozmetik adı verilen allık, ruj gibi ürünlerde kullanılan hammaddelerden dolayı ağır metal analizlerinin gerçekleştirilmesi gerekmektedir. Kozmetiklerde Yapılması gereken ağır metal analizleri kurşun, kadmiyum, civa, arsenik ve antimondur.

İçermez testleri ve iddia testleri: Sağlık Bakanl1ğının yayınladığı kılavuz gereği etikette "paraben içermez", "silikon içermez", "fitalat içermez" gibi ifadeler yer alıyorsa bununla ilgili analizlerin yaptırilması zorunludur.

Mikrobiyolojik analizler: Kozmetik ürünler mikrobiyolojik açıdan güvenli olmak zorundadır.Düşük riskli birkaç kozmetik dışında (saç boyaları vb.) mikrobiyolojik analiz tüm kozmetik ürünler için önem arz etmektedir. Özellikle bebek ürünleri ve göz çevresi ile temas eden ürünler bu açıdan çok daha fazla risklidir. Başta patojenler olmak üzere toplam bakteri ve küf-maya analizlerinin yapılması gerekmektedir.

Koruyucu etkinlik testi (challenge test): Koruyucu etkinlik testleri (challenge test) üründe kullanılan koruyucuların mikroorganizmalara karşı etkinliğini gösteren testlerdir [17].

Ülkemizde kozmetik alanında akredite laboratuvarlarda kozmetik deneyleri ağırlıklı olarak: ISO Standartları (ISO), Türk Standartları (TS), Avrupa Farmakopesi, Amerikan Farmakopesi, OECD Kılavuzları (Örneğin: OECD Guideline For The Testing of Chemicals), Avrupa Birliği Kozmetik Mevzuatının 76/768/EEC sayıl1 Konsey Direktifi, IS 3986: Sodium Lauryl Sulphate for Cosmetic Industry, IS 11487: Specification For Sodium Lauryl Ether Sulphate For Cosmetic Industry, AOCS Beklentileri, NMKL 161, NMKL 170, EPA Metotlar1, Deterjan ve Deterjanlarda Kullanılan Yüzey Aktif Maddeler Hakkında Tebliği, Sayı: 28807 , Kozmetik Ürün Bileşimlerinin Kontrolü İçin Gerekli Analiz Yöntemleri Hakkında Tebliğ (Tebliğ No: İEG-2005/7), İşletme içi metotlar çerçevesinde yürütülmektedir[23].

\subsection{Kozmetik Laboratuvarlarında Akredite}

\section{Olmanın Yararlart}

Akreditasyon, yetkinliğin tanınmasıdır. Laboratuvarlar için akreditasyon kriteri TS EN ISO/IEC 17025 standardıdır. Bu standart, bir laboratuvar, deney faaliyetleri gerçekleştirmek için yetkin olarak tanınacaksa, faaliyetleri için uygulamak zorunda olduğu genel gereklilikleri belirtir. Akreditasyon, laboratuvarın TS EN ISO/IEC $17025^{\prime}$ in şartlarını taşıdığı anlamına gelir. Akreditasyon, laboratuvarların yetkinliklerini sürdürmek için bir referans sağlar. Bu tanınmayı sürdürmek için, laboratuvarların, akreditasyon kurumu tarafından, şartlara uygunluğunun sürdürüldüğünden emin olunması ve ilgili standardın sürdürüldüğünün kontrolü için periyodik olarak denetlenir. Akreditasyon kurumu tarafından gerçekleştirilen düzenli denetimler sayesinde, laboratuvarlar tarafından yürütülen deney ve kalibrasyon faaliyetlerinin güvenilirliğinin sürekliliği hakkındaki tüm parametreler kontrol edilir. Her denetim sonunda, iyileştirmeye açık alanlar tanımlanır ve tartışılır ve detaylı olarak raporlandırilır.

Akreditasyon, laboratuvarlar için etkili bir pazarlama aracıdır. Laboratuvarın listelenen akreditasyon kapsamını yürütmek için yetkin olduğunu destekler. Laboratuvarlara, teknik olarak geçerli ve uluslararas1 tanınırlığa sahip prensipler doğrultusunda faaliyet gösterildiği ve analizlerin amaçlanan kullanıma uygunluğu hakkında güven verir. Bu kullanımlar ölçüm metotlarının kesinlik ve doğruluğunun değerlendirilmesi, kalite kontrol, malzemelere değer atanması, kalibrasyon ve geleneksel skalaların oluşturulmasını içerir.

Kozmetik ürünlerin pek çok farklı kullanım alanı olması nedeniyle bu ürünlerin kullanıcı kitlesi dünya nüfusunun büyük bir çoğunluğunu oluşturmaktadır. Aynı zamanda insan sağlığına olan doğrudan ya da dolaylı etkisi ile bu ürünler için beklenen güven seviyesi giderek artmaktadır. Kullanıcı için güveni oluşturmanın en tarafsız ve kalıcı yöntemlerinden birisi uluslararası geçerliliğe sahip olan akreditasyon sistemine dahil olmaktır. Bu nedenle, ister bağımsız bir kozmetik laboratuvarı olsun ister bir kozmetik üreticisi firmanın parçası olsun, kozmetik ürünlerin analizleri ürün kalitesine doğrudan etki etmektedir. Ülkemizde kozmetik ürünlerin yasal mevzuatından sorumlu olan TITCK tarafindan belirlenen yasal gereklilikler doğrultusunda kozmetik ürünlerin piyasaya arzı beyan sonucu mümkün olabilmektedir. $\mathrm{Bu}$ noktada akreditasyona sahip olan kozmetik laboratuvarlarının kullanıcı nezdinde her daim tercih önceliği olabileceği unutulmamalıdır.

Dünyadaki birçok ekonomik yaklaşım, laboratuvarlar için akreditasyonu önermektedir. Bu durum, ekonomilerin laboratuvar yetkinliğini tespit etmek için ortak bir yaklaşım sergilemesine yardımcı ol- 
maktadır. Bu tek tip yaklaşım, farklı ülkelerdeki akreditasyon kuruluşlarının karşılıklı değerlendirme ve birbirlerinin akreditasyon sistemlerinin kabulüne dayalı olarak kendi aralarında düzenlemeler yapmalarına izin verir. ILAC, laboratuvar akreditasyonu için karşılıklı tanıma anlaşması adına bir süreç işletmektedir[24,25].

Bununla birlikte akredite laboratuvar sayısı giderek artış göstermektedir. Akreditasyon kurumlarının Avrupa Akreditasyon Birliği (EA) ve Uluslararası Laboratuvarı Akreditasyonu Komitesi (ILAC) çatısı altında birleşmesi ile akredite laboratuvarlar tarafından gerçekleştirilen deney faaliyetleri dünya çapında kabul görmesine yardımcı olmaktadır.

Akreditasyonun uygunluk değerlendirme kuruluşlarına sağladığı yararlar özet olarak;

- Spesifik alanlarda kanıtlanmış yetkinliklere sahip uygunluk değerlendirme kuruluşlarının resmen tanınması,

- Laboratuvarların test tekrarı ve değerlendirmelerin bertaraf edilmesi veya azaltılması (zaman ve kaynak tasarrufu),

- Laboratuvarların kullandığı test metotlarının güncel kılınması,

- Kapasite üzerine olumlu etki göstermesi,

- Saygınlık ve ticari üstünlük,

- Üçüncü taraflar tarafından tanınması nedeniyle laboratuvarın tek bir denetimden geçmesini sağlayarak çoklu denetimleri önlemesi (Bazı kamu otoriteleri tarafindan zorunlu olan denetimler hariç),

- Deneylerin kalite düzeylerinin atması,

- Kalitenin sürekliliği ve güvenilirliğinin disiplin altına alınması,

- Müşteri memnuniyetinin artması,

- Personelin teknik yeterliliğine olumlu katk1,

- Cihaz ve ekipmanların sürekli bakımı ve kontrolü,

- Kaynakların iyileştirilmesi,

- Çalışanların yetki ve sorumluluklarının belirlenmiş olması,

- Kişisel yaklaşımlardan süreç yaklaşımlarına dönüşüm sağlamas1,

- Akredite laboratuvarların ürettiği test sonuçlarının iç pazar ve uluslararası pazarlarda kabul görmesi [24].
Akreditasyonun Müşteri/ Kullanıcıya sağladığı faydalar ise;

- Ürün ve hizmetlerin belirtilen özellikleri karşıladığıına dair bütünlük ve güven,

- Kurum tarafindan kullanılan prosedürlerin güvenilirliği ve doğruluğu,

- Ürün ve hizmetlerin kolayca ve güvenilir bir şekilde karşılaştırılabilirliğii,

- Ölçüm süreçlerinin değerlendirme zinciri boyunca izlenebilirliği,

- Kalite altyapısının yetkin olması ve teknik yeterliliğin görülmesi,

- Ürünler ve süreçlerin bir standardın şartlarına uygunluğu,

- Ürün veya hizmet değerlendirme süreci uygulamalarının ve prosedürlerin erişilebilir ve şeffaf olmas1,

- Kurumların tarafsızlığ den korunmasidir [24].

\section{SONUÇ}

Akreditasyon, uygunluk değerlendirme kuruluşlarınca gerçekleştirilen faaliyetlerin güvenilirliğini ve geçerliliğini desteklemek amacıyla oluşturulmuş bir kalite altyapısıdır. Kozmetik laboratuvarlarının akreditasyonu, yeterlilik kriterlerini belirleyen uluslararası standartlar, ilgili faaliyet alanına özel gereklilikler ve bölgesel veya uluslararası akreditasyon kuruluşları tarafından belirlenmiş rehber dokümanlarda belirlenmiş, dünya genelinde kabul görmekte olan gereklilikler esas alınarak gerçekleştirilmektedir. Kozmetik laboratuvarlarının akreditasyonu için TS EN ISO/IEC 17025 standardının gereklilikleri yerine getirilmelidir.

Akredite bir kozmetik laboratuvarı tarafindan düzenlenen bir analiz raporu, uluslararası standartlara uygunluğa dair güven telkin eder. Bu sistematik sayesinde akreditasyon ticarette teknik engellerin kaldırılmasına katkıda bulunmaktadır [26]. Ülkemizde, yasal otoriteler tarafindan yetkilendirme aşamasında zorunlu tutulmadıkça akreditasyon, gönüllü bir hizmettir. Kozmetik ürünlerin piyasaya arzında T.C. Sağlık Bakanlığı Türkiye İlaç ve Tıbbi Cihaz Kurumu'na (TITTCK) yapılan bildirim esas alınmakta olup üreticiler TİTCK tarafından piyasa gözetim denetimlerine tabi tutulmaktadır. Yapılan bildirimler 
esnasında akreditasyon koşulu aranmamaktadır.

Kozmetik alanındaki akredite laboratuvar sayısının nispeten daha az olmasında bu alandaki akreditasyonun gönüllülük esasına dayanmasının etkisi büyüktür. Akreditasyon, her ne kadar gönüllülük esasına göre yürütülüyor olsa da dünya ekonomisindeki ve ticaretindeki eğilimler ve beklentiler sebebiyle sürekli artan rekabet piyasasında avantaj sağlamak amacıyla zorunlu hale gelmektedir. Gelişen, değişim gösteren dünyamızda bu durumun olması kaçınılmazdır. Kozmetik ürünlerde açıldıkları andan itibaren çevreden ve kullanıcının cildiyle temastan dolayı sürekli ve özellikle çeşitli mikrobiyolojik kontaminasyon olasılığı bulunmaktadır. Bu nedenle, hayatın içinde pek çok alanda mevcut olan kozmetiklere ilişkin teknik gerekliliklerin bağımsız bir kurum tarafından denetlenmesi, ürünlere olan güveni artırmanın kaçınılmaz bir yoludur.

Türkiye İlaç ve Tıbbi Cihaz Kurumu Kozmetik Ürünlerin Mikrobiyolojik Kontrolüne İlişkin Kılavuz (Sürüm 1.0)' e göre, "Makul bir kalite seviyesi sağlanması için kozmetik ürünlerde mikrobiyolojik incelemelerin yapıldığı laboratuvarlar TS EN ISO 9000'de belirtilen kalite yönetimi standartlarına ve TSE EN ISO 17025'de belirtilen test ve kalibrasyon laboratuvarlarının yeterliliği için genel gerekliliklere uygun olmalıdır. Analizin kalitesiyle ilgili bütün belgeleri kontrol etmek için prosedürler oluşturmalı ve devam ettirmelidir. Bu prosedürler TS EN ISO 17025 ve TS EN ISO 22716'daki gerekliliklere uymalıdır [27]."

Bir yandan, tüm dünyada Mart 2020' den bu yana görülen Covid-19 pandemisi nedeniyle hijyen ürünlerine olan ilgi giderek artmaktadır. Hijyen ürünleri kapsamında değerlendirilen dezenfektan ve antiseptik ürünler de "kozmetik" alanı içerisinde denetlenmektedir.

Pandemi koşullarında bu ürünlere olan talep ve ihtiyaç arttığı için bu ürünlerin analizini yapan laboratuvarların sayısı da artmıştır. Bu artış, salgın koşullarının tüm dünyada geçerli olması, dolayısıyla, verilen hizmetin uluslararası boyut kazanması gerekliliğini de ortaya koymuştur. Bu nedenle son dönemde hijyen ürünleri kapsamında TÜRKAK'a ulaşan akreditasyon başvurularında artış söz konusudur.

TÜRKAK'ın Avrupa Akreditasyon Birliği (EA) ile imzaladığı çok taraflı tanınma anlaşması çerçevesinde, akredite olan laboratuvarlar tarafindan gerçekleştirilen analizler EA' ya üye olan tüm ülkelerde ge- çerlidir. Mevcut durumda EA'ya tam üye olan ülke sayıs1 47'dir [28]. Bu durum, akreditasyon kapsamındaki analizlerin güvenilirliğini oldukça ön plana taşımaktadır.

Derleme kapsamında kozmetik laboratuvarlarının akreditasyonu hususunda, akredite laboratuvar say1sının artırılması başta olmak üzere kozmetik laboratuvarları tarafından gerçekleştirilen analizlerin kalite ve güvenilirliğinin artırılmasına yönelik öneriler aşağıda belirtilmiştir:

Dünya ekonomisinde kozmetik alanının giderek daha büyük paya sahip olması ve dolayısı ile bu alanda ihtiyaç duyulan istihdam oranının giderek artması yadsınamaz bir gerçektir. Nitelikli istihdamın sağlanabilmesi ise personelin bu alanda gerekli eğitimi alması ile mümkündür. Kozmetik üretimi ve analizlerinde ürünün kalitesine etkisi olan her bir personelin uygun kalifikasyona sahip olması aynı zamanda TS EN ISO/IEC 17025 standardında da açıkça belirtilen bir husustur.

Personelin kalifikasyonu kozmetik ürün kalitesi ve analiz sonuçlarına katkı sağlayacağı için akreditasyon denetimlerinin etkinliğini artıracaktır. Derleme için yapılan araştırmada, akredite kozmetik laboratuvarlar tarafından gerçekleştirilen analizlerin genel çerçevede ISO Standartları (ISO), Türk Standartları (TS), Avrupa Farmakopesi, Amerikan Farmakopesi, OECD Kılavuzları (Örneğin: OECD Guideline For The Testing of Chemicals), Avrupa Birliği Kozmetik Mevzuatının 76/768/EEC sayılı Konsey Direktifi, IS 3986: Sodium Lauryl Sulphate for Cosmetic Industry, IS 11487: Specification For Sodium Lauryl Ether Sulphate For Cosmetic Industry, AOCS Beklentileri, NMKL 161, NMKL 170, EPA Metotları, Deterjan ve Deterjanlarda Kullanılan Yüzey Aktif Maddeler Hakkında Tebliği, Sayı: 28807, Kozmetik Ürün Bileşimlerinin Kontrolü İçin Gerekli Analiz Yöntemleri Hakkında Tebliğ (Tebliğ No: İEG-2005/7), işletme içi metotlar kapsamında yürütüldüğü tespit edilmiştir (Bkz: Başlik 3.3). Bu kapsamda, TÜRKAK denetimlerinde kozmetik laboratuvarlarında akreditasyon kapsamındaki parametrelere yönelik validasyon, verifikasyon ve ölçüm belirsizliği hesaplamalarında bilgi eksikliği olduğu tespit edilmiştir. Türkiye İlaç ve Trbbi Cihaz Kurumu Kozmetik Ürünlerin Analizlerine İlişkin Kılavuz' a göre; "Yöntemlerin validasyonu için TS EN ISO/IEC 17025 standard1, TS 58221 ISO 5725-1, TS 5822-2 ISO 5725-2, TS 5822-3 ISO 5725-3, TS 5822-4 ISO 5725-4, TS 5822-5 ISO 5725-5 ve TS 5822-6 ISO 5725-6 standartla- 
rı (Ölçme metotlarının ve sonuçlarının doğruluğu standartları, 6 bölüm) veya ilgili IUPAC kılavuzları kullanılabilir[3]." Bu alandaki eğitim, kurumsal oryantasyon kapsamında verilebileceği gibi, üniversitede lisans, yüksek lisans ve doktora kapsamında verilmesi teknik personellerin iş yaşamına daha hızlı adapte olmasına yardımcı olabilir. Ülkemizde eczacılık, kimya mühendisliği, biyoloji, kimya vb. bölümlerinin ders kapsamlarında validasyon ve ölçüm belirsizliğine yönelik yeterli içerikte bir eğitim verilmediği görülmüştür. Bu nedenle, ülkemizde yürütülen kozmetik analizlerinin gelişimine katkı sağlamak amacıyla yükseköğretim kurumlarında özellikle kozmetiklere yönelik bilim dallarında validasyon ve ölçüm belirsizliği kapsamındaki derslerin artırılması önerilmektedir.

Kozmetik alanı, son yıllarda hızlı büyümesiyle dikkat çeken alanların başında gelmektedir. Genç nüfus, kadınların genç ve güzel görünme tutkusu, erkeklerin kişisel bakımına daha fazla önem vermesi, e-ticaretin gelişmesi ve doğrudan satışın artması bu büyümeye büyük oranda katkı sağlamaktadır.

$\mathrm{Bu}$ alanın katma değerli ihracat potansiyeli oldukça yüksektir. Bu nedenle alanda yerli üretimin artırılmas1 amacıyla çalışmalar yapılmalıdır. Ülkemizde, Hacettepe Üniversitesi, Gazi Üniversitesi, TOBB Üniversitesi, Anadolu Üniversitesi, Marmara Üniversitesi, Yeditepe Üniversitesi, Ege Üniversitesi başta olmak üzere diğer bazı üniversitelerde de kozmetoloji programında eğitim verilmektedir. Bu üniversitelerde yetişen öğrencilerin üretim odaklı eğilimle eğitim alması ülkemizde yerli kozmetik üretiminin artmasına katkı sağlayacaktır.

\section{KAYNAKLAR}

1. https://www.turkak.org.tr/akreditasyon/akreditasyon-nedir. html [Internet]. [Erişim Tarihi: 17 Haziran 2021]

2. TÜRK AKREDİTASYON KURUMU, Akredite Kuruluş Arama Sayfası [İnternet]. Erişim tarihi: Haziran 2021, Erişim adresi: https://secure.turkak.org.tr/kapsam/search

3. Türkiye İlaç ve Tıbbi Cihaz Kurumu Kozmetik Ürünlerin Analizlerine İlişkin Kılavuz, https://titck.gov.tr/storage/legislation/GZILm67v.pdf [Internet]. [Erişim Tarihi: 17 Haziran 2021]

4. Bakanlıklara Bağlı, İlgili, İlişkili Kurum ve Kuruluşlar ile Diğer Kurum ve Kuruluşların Teşkilatı Hakkında Cumhurbaşkanlığı Kararnamesi, Kararname Numarası: 4, Türk Akreditasyon Kurumu ile İlgili Bölüm
5. https://ilac.org/ilac-membership/members-by-category/ [Internet]. [Erişim Tarihi: 17 Haziran 2021]

6. Türk Akreditasyon Kurumu 2017 Y11 Faaliyet Raporu, Ankara: Türk Akreditasyon Kurumu; 2018. 104

7. ISO 17025 Standard1. Deney ve Kalibrasyon Laboratuvarlar1nın Yeterliliği için Genel Gereklilikler

8. TÜRKAK R20.43, R20-43 Laboratuvarların Akreditasyonuna Dair Rehber, 2021 TÜRKAK

9. Mehta, B. (2019). Implementing ISO/IEC 17025:2017. American Society for Quality, Quality Press, Milwaukee 53203 https://play.google.com/books/reader?id=kem PDwAAQBAJ\&hl=tr\&pg=GBS.PA1 [Internet]. [Erişim Tarihi: 17 Haziran 2021]

10. Ellison, S. L. R., Willians, A. (2019). Eurachem/CITAC Guide: Metrological traceability in chemical measurement. www. eurachem.org [Internet]. [Erişim Tarihi: 17 Haziran 2021]

11. United Nations Industrial Development Organization (UNIDO), Complying With ISO 17025 A Practical Guidebook For Meeting The Requirements Of Laboratory Accreditation Schemes Based On ISO 17025:2005 Or Equivalent National Standards, Vienna, 2009

12. TÜRKAK R10.12, R10-12 Ölçümlerin İzlenebilirliği Rehberi. TÜRKAK

13. TÜRKAK P704 Yeterlilik Deneyleri ve Laboratuvarlar Aras1 Karşılaştırma Programları Prosedürü, 2021, TÜRKAK

14. Bureau International Des Poids Et Mesure (BIPM), Guide To The Expression Of Uncertainty In Measurement, 2008

15. NORDTEST TR 537 Çevre Laboratuvarlarında Ölçüm Belirsizliği Hesaplamaları (NT TR 537), Oslo, 2013

16. ILAC G8:09/2019 Guidelines on Decision Rules and Statements of Conformity, 2021

17. TÜRKIYE İLAÇ VE TIBBİ CIHAZ KURUMU, Kozmetik Ürünlerde Güvenlilik Değerlendirmesine İlişkin Kılavuz (Sürüm 2.0)

18. ISO/IEC 17025 Standart Revizyonu Bilgilendirme Kilavuzu - Laboratuvar Bilgi Yönetim Sistemleri (LIMS), 2021,TÜRKAK

19. TS ISO 31000 Risk Yönetimi - Prensipler ve Kilavuzlar, 2018, TSE

20. ISO/IEC 17025 Standart Revizyonu Bilgilendirme Kılavuzu Risk Temelli Düşünce, 2021, TÜRKAK

21. TS EN ISO 9000 Standardı. Kalite Yönetim Sistemleri - Temel Esaslar, Terimler ve Tarifler

22. Türk Akreditasyon Kurumu (TÜRKAK), P701 Uygunluk Değerlendirme Kuruluşlarının Akreditasyonu, Gözetimi ve Akreditasyonun Yenilenmesine İlişkin Prosedür, Ankara, 2017 
23. R20-27 Kimya Laboratuvarları için Akredite Edilecek Kapsam Beyanı Rehberi, 2021, TÜRKAK

24. ILAC B13 Why become an Accredited Reference Material Producer.

25. Agarwal, R., Bagajda, C. and Green, R. (2017). Economic Value of NATA Accreditation in Australia, University of Technology, Sydney.

26. Türk Akreditasyon Kurumu Sikça Sorulan Sorular, [Internet]. 2020 [Erişim Tarihi 8 Ağustos 2020]
27. Türkiye İlaç ve Tibbi Cihaz Kurumu Kozmetik Ürünlerin Mikrobiyolojik Kontrolüne İlişkin Kılavuz (Sürüm1.0), 2021

28. EA Annual Report, European Accreditation. 2020, https:// european-accreditation.org/wp-content/uploads/2021/04/EAAnnual-report-2020-1.pdf, [Internet]. [Erişim Tarihi: 17 Haziran 2021]

\section{KISALTMALAR}

\begin{tabular}{|c|c|}
\hline ARAC & Arap Akreditasyon İşbirliği \\
\hline BIPM KCDB & Uluslararası Ağırlıklar ve Ölçüler Bürosu Anahtar Karşılaştırma Veritabanı \\
\hline CIPM MRA & Uluslararası Ölçüler ve Ağırlıklar Komitesi Karşılıklı Tanıma Düzenlemesi \\
\hline EA & Avrupa Akreditasyon Birliği \\
\hline $\mathbf{E N}$ & Avrupa Standard 1 \\
\hline GDPR & Avrupa Genel Veri Koruma Yönetmeliği \\
\hline IAAC & InterAmerican Akreditasyon İşbirliği \\
\hline IAF & Uluslararası Akreditasyon Forumu \\
\hline IEC & Uluslararası Elektroteknik Komisyonu \\
\hline ILAC & Uluslararası Laboratuvar Akreditasyon Birliği \\
\hline IRM & Risk Yönetim Enstitüsü \\
\hline ISO & Uluslararası Standardizasyon Örgütü \\
\hline İLU- GLP & İyi Laboratuvar Uygulamaları \\
\hline KHK & Kanun Hükmünde Kararname \\
\hline LAK & Laboratuvarlararası Karşılaştırma \\
\hline NMKL & Gıda Analizleri alanında İskandinav Ülkeleri Birliği \\
\hline OECD & Ekonomik Kalkınma ve İşbirliği Örgütü \\
\hline TİTCK & Türkiye İlaç ve Tıbbi Cihaz Kurumu \\
\hline TS & Türk Standardı \\
\hline TSE & Türk Standartları Enstitüsü \\
\hline TÜRKAK & Türk Akreditasyon Kurumu \\
\hline UDK & Uygunluk Değerlendirme Kuruluşu \\
\hline YGG & Yönetimin Gözden Geçirmesi \\
\hline YT & Yeterlilik Testi \\
\hline
\end{tabular}

